\title{
Evaluation of Rremineralization Capacity of Non-fluoride Home Products
}

\author{
DAN NEGRAIA ${ }^{1}$, SIMONA STOLERIU2*, GIANINA IOVAN², IRINA NICA², ANDREI GEORGESCU², CLAUDIU TOPOLICEANU², \\ SORIN ANDRIAN², DIANA LACATUSU 3 \\ ${ }^{1}$ Dunarea de J os University Galati, Faculty of Medicine and Pharmacy, 47 Domneasca Str., 800008 Galati, Romania \\ ${ }^{2}$ Grigore T. Popa University of Medicine and Pharmacy lasi, Faculty of Dental Medicine, 16 Universitatii Str., 700115 Iasi, Romania \\ ${ }^{3}$ Grigore T. Popa University of Medicine and Pharmacy lasi, Faculty of Pharmacy, 16 Universitatii Str., 700115 lasi, Romania
}

\begin{abstract}
The aims of the study were to characterize enamel, dentine and cementum surface aspect after using nonfluoride remineralization toothpastes containing calcium carbonate and calcium glycerophosphate by SEM evaluation, to determine chemical composition of enamel, dentin and cement after remineralization products application by EDX assessment, and to compare the remineralization capacity of the tested products. Ten extracted teeth having no dental caries, erosive or wear lesions were selected for the study. The teeth were split bucco-lingually and mesio-distally in four pieces. A free window of enamel, dentine, and cementum $(4 X 4 \mathrm{~mm})$ in the cervical area of the slices was preserved. In control group the slices were subjected to a artificial caries lesion formation. In study groups EcoBio ${ }^{\circledR}$ (President Company), Bio-natural (Dentissimo, Swiss Biodent), and Arthrodont Cassic (Pierre Fabre Oral Care) toothpastes were applied two times a day, for 3 minutes during caries lesion formation. The surface topography has been analyzed using a scanning electron microscope and the quantitative and qualitative chemical composition has been evaluated using an EDX detector. Interprismatic and intraprismatic mineral loss is clearly visible at higher magnification in enamel samples in control group. Some areas of demineralization are still present, and also small areas of extern deposits are visible on enamel, dentine and cementum samples in the groups were tested products were applied. All the tested toothpastes increased calcium and phosphorous ion concentrations in enamel, dentine and cementum. The highestremineralization effect was recorded in enamel by Dentissiomo, followed by Arthrodent and EcoBio toothpastes. In dentine and cementum the highest remineralization effect was registered by Arthrodent, followed by Dentissiomo and EcoBio toothpastes.
\end{abstract}

Keywords: calcium carbonate, calcium glycerophophate, remineralization, enamel, dentine, cementum

In oral environment the teeth and the materials for restoration are exposed to diverse acidic or mechanical challenges that lead to dental hard tissues demineralization [1] or wear [2], to material degradation [3,4] and to material-tooth interface failure [5-7].

The term remineralization has been previously used by certain authors to describe mineral gain, including mineral precipitation on tooth surfaces [8], but precipitation represents the build-up of ionic clusters in an oversaturated solution taking the shape of a solid phase. Nowadays, remineralization can be defined as the process where calcium and phosphate ions are supplied from a source external to the tooth to promote ion deposition into crystal voids in demineralized enamel, to produce net mineral gain [9].

The remineralization of hard dental tissues requires the presence of partially demineralized crystals when exposed to contact with oversaturated fluids; compared to minerals in hydroxyapatite they may increase up to their original size. Previous studies have determined that the net remineralization promoted by saliva is reduced and that it seems to be limited especially to the superficial, virtually integral layer of the caries lesion [10]. It is unanimously accepted that saliva represents a source of inorganic ions necessary in the remineralization process, thus ensuring the amount of calcium and phosphate ions. It has been proven that the enamel surface softened by acidic drinks could be reconsolidated by subsequent exposure to saliva [11].
Biomimetic remineralization represents the natural repair process specific to the body of subsurface noncavitated caries lesions and it is based on the calcium and phosphate ions; with the help of fluoride ions, they rebuild a new surface of the remaining subsurface crystals after demineralization. These remineralized crystals are resistant to acids and they are significantly less soluble than the original mineral [12]. In the therapeutic remineralization process, calcium and phosphate ions are brought from external sources onto the tooth in order to promote their deposition in the pores within the crystal of the demineralized enamel, thus leading to a net mineral gain.

It has been highlighted that it is very difficult for calcium and phosphate ions to diffuse in the deepest layers of the carious enamel, reason for which most of the remineralization process is limited to the surface of the carious lesion. Insofar as it favours remineralization, calcium will be rapidly adsorbed on the superficial layer and it will precipitate onto the pores, thus blocking access towards the inside of the carious enamel lesion [13].

A more complete remineralization occurs when the concentrations of calcium and phosphate are lower, coming first of all from the saliva butalso from other topical sources, thus having the capacity of diffusing inside the tooth; with the help of fluoride or of another remineralizing agent, to rebuild the partially demineralized crystals rather than to form new crystals.

Due to the dissemination of the application of fluoride and of the current knowledge on its mechanisms of action, 
Table 1

CHEMICAL COMPOSITION OF THE TOOTHPASTES INCLUDED IN THE STUDY

\begin{tabular}{|c|c|c|}
\hline Toothpaste & Composition & Producer \\
\hline Arthrodont Cassic & $\begin{array}{l}\text { Aqua, Calcium carbonate, Glycerin, Sodium laureth sulfate, } \\
\text { Algin, Glycyrrhetinic acid, Chondrus crispus extract, Eugenol, } \\
\text { Aroma, Hydrated sodium silicate, Illicium verum oil, } \\
\text { Limonene, Mentha piperita oil, Menthol, Propylparaben, } \\
\text { Saccharin }\end{array}$ & Pierre Fabre \\
\hline Dentissimo Bio-natural & $\begin{array}{l}\text { Calcium Carbonate, Xylitol, Calcium Glycerophosphate, } \\
\text { Sage, Chamomilla, Geranium, Maculatum, Bisabolol, Mentha } \\
\text { Piperita }\end{array}$ & $\begin{array}{c}\text { Dentissimo, Swiss } \\
\text { Biodent }\end{array}$ \\
\hline EcoBio & $\begin{array}{l}\text { Calcium carbonate, glycerin, water, xylitol, sorbitol, } \\
\text { chamomile extract, sage extract, thyme extract, echinacea } \\
\text { extract, bisabolol, silicon dioxide, alcohol, eucalyptol, calcium } \\
\text { glycerophosphate, tea tree oil, eucalyptus oil, anethole. }\end{array}$ & President Company \\
\hline
\end{tabular}

the topical applications of fluoride (toothpastes, gels, varnish and mouthrinses) are considered effective on demineralization inhibition and remineralization encouraging [14]. Fluoride levels of three parts per million (ppm) are necessary in order to modify balance from net demineralization to net remineralization. Studies showed the efficacy of fluoride in enamel, dentine and cement remineralization [15-18].

Certain remineralizing alternatives, generically named topical non-fluoridated remineralizing agentswere introduced in clinical practice. They have been sold as toothpastes, chewing gums or varnish and they have been tested in other vehicles such as lozenges, mouthrinses, foods and drinks [19].

The aims of the study were to characterize the enamel, dentine and cement surface after using non-fluoride remineralization toothpastes containing calcium carbonate and calcium glycerophosphate by SEM evaluation, to determine chemical composition of enamel, dentin and cement after remineralization products application, and to compare the remineralization capacity of the tested products.

\section{Experimental part}

Artificial caries lesions formation and tooth surface remineralization

Our study was done in accordance with the Ethical Committee regulations and in accordance to some published models $[20,21]$. For this study were used 10 extracted teeth having no dental caries, erosive or wear lesions. The selected teeth also presented a free dentine area between enamel and cement in the cervical area. The teeth selection according to these criteria was made by evaluation using an optical microscope (Nikon Eclipse E 600, Nikon, Japan) at a 10X magnification. The teeth were split bucco-lingually and mesio-distaly in four pieces using diamond discs (KometDental, Brasseler GmbH\&Co, Germany), under watercooling. The extern part of the slices was covered with acid resistant varnish (Resist and shine, L'Oreal, Paris). A free window of enamel (E), dentine (D) and cement (C) (4X4 $\mathrm{mm}$ ) in the cervical area of the slices was preserved. The slices were randomly divided in four groups (A-D).

In control group (group A) the slices were subjected to a demineralization period of $1 \mathrm{~h}$, three times a day, 14 days.
The chemical composition of the demineralization solution, having a $\mathrm{pH}$ of 5 , was: $1.5 \mathrm{mM} \mathrm{CaCl}_{2}, 0.9 \mathrm{mM} \mathrm{KH}_{2} \mathrm{PO}_{4}, 150$ $\mathrm{mM} \mathrm{KCl}, 0.1 \mathrm{mM}$ sodium acetate. Between demineralization cycles, the samples were stored in artificial saliva (AFNOR NF S90-701). In groups B, C and D the same demineralization cycles wereapplied, but the first and the last demineralization period were followed by the application of EcoBio $\AA$ toothpaste (President Company) for 3 minutes (group B), Bio-natural (Dentissimo, Swiss Biodent) for 3 min (group C) and Arthrodont Cassic (Pierre Fabre Oral Care) for 3 minutes (group D). Chemical composition of the tested toothpastes is presented in table 1.

To simulate the toothbrushing, a medium toothbrush according to the bristles hardness (Classic Deep Clean, Colgate) was used and toothpaste slurries were obtained by mixing the toothpastes with water $1: 3$ in volume. The teeth were placed in a special machine which simulates the movements during toothbrushing. A $250 \mathrm{~g}$ loading force was applied on eachtoothbrush and a time of 2 min was established for each toothbrush.

\section{Surface topography and chemical analysis}

The surface topography has been analyzed using a scanning electron microscope VEGA II LSH (TESCAN, Czech Republic) and the quantitative and qualitative chemical composition has been evaluated using an EDX detector (QUANTAX QX2, BRUKER/ROENTEC, Germany). Five different areas in enamel, dentine and cementum were evaluated for each sample.

\section{Results and discussions}

SEM aspects of enamel in some samples in groups A-D are presented in figure 1. Large area of enamel demineralization are present on the samples in group $A$. Interprismatic and intraprismatic mineral loss are clearly visible at higher magnification (SEM X 1000). Small area of demineralization are still presentin group D. Mineral loss is rarely visible at higher magnification. In group $C$ large areas of demineralization are still present. Interprismatic and intraprismatic mineral loss is visible, but narrow areas of remineralization can be seen. In group B some small areas of demineralization are still present, but extensive areas of remineralization can be seen.

Large area of dentine demineralization are present in group A (fig. 2). In groups B, C and D some area of 

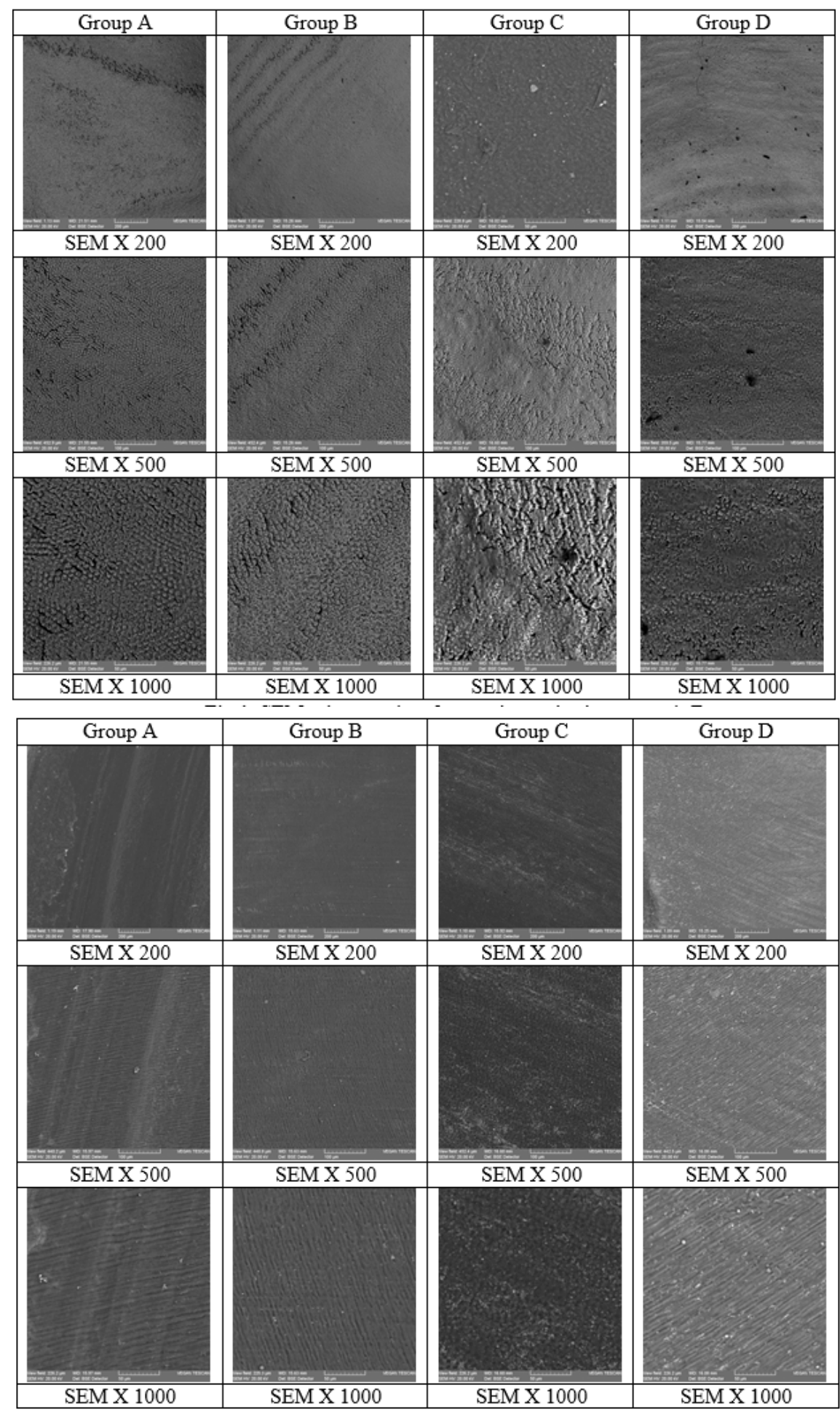

Fig.1. SEM micrographs of enamel samples in groups A-D
Fig.2. SEM micrographs of dentine samples in groups A-D demineralization are still present, but small areas of extern deposits are visible.

In group A cementum surface presented extended area of demineralization (fig. 3). Very rare and small area of demineralization are still present in group $B, C$, and D, but large deposits are visible on the surface.

Enamel, dentine, and cementum EDX spectrum analysis revealed mostly calcium, phosphorous and oxygen ions presence. The mean calcium and phosphorous ion concentrations (wt\%) in groups A-D are presented in table 2. Increased calcium and phosphorus ion concentrations was recorded in groups $B, C$, and $D$ when compared to group $A$. In enamel, the highest values of calcium and phosphorus ion concentrations were recorded in group $C$, followed by group $D$ and group $B$. In dentine, the highest values of calcium and phosphorus ion concentrations were recorded in group $D$, followed by group $C$ and group $B$. In cementum, the highest values of calcium and phosphorus ion concentrations were recorded in group D, followed by group $C$ and group $B$. The low est calcium ion concentration was found in cementum (2.23 wt\% in group A) and the highest in enamel ( $44.53 \mathrm{wt} \%$ in group C). The lowest phosphorous ion concentration was found in cementum ( 0.73 wt\% in group A) and the highest in enamel (20.12 wt\% in group C).

Mean ions values were statistically analyzed using nonparametric Mann Whitney test. Significantly statistical differences $(p<0.05)$ were obtained when compared calcium and phosphorous ions concentrations in enamel, dentine, and cementum in groups $B, C$, and respectively $D$ when compared to group $A$, and also when compared the groups B, C, and D (table 3 and table 4).

The concentrations of calcium and phosphate ions modulate the kinetics of dissolution of remineralization of the enamel, considering that a decrease in oral $\mathrm{pH}$ requires 


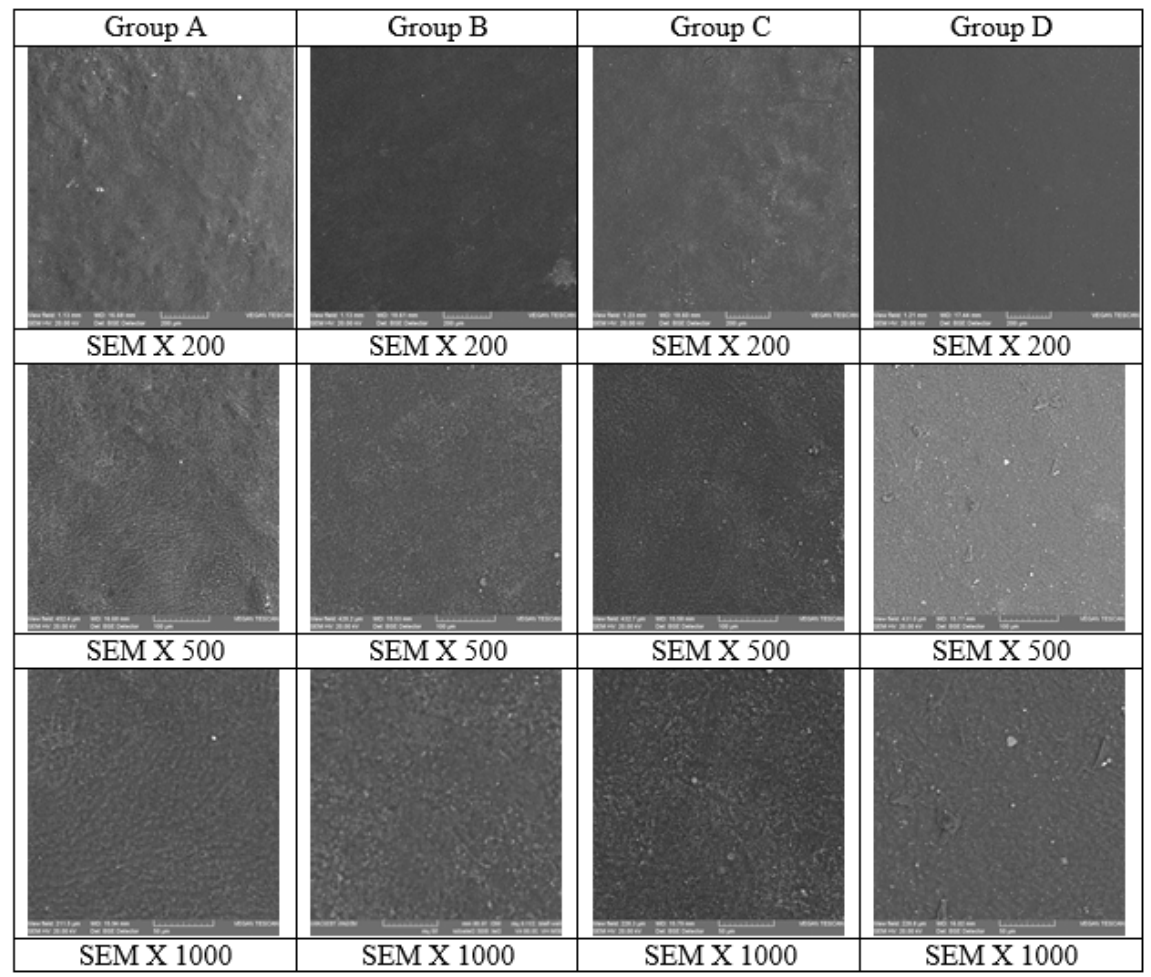

Fig.3. SEM micrographs of cementum samples in groups A-D

Table 2

MEAN CALCIUM AND PHOSPHOROUSION CONCENTRATIONS (WT \%) \pm STANDARD DEVIATION IN GROUPS A-D

\begin{tabular}{|l|c|c|c|c|c|c|}
\hline & \multicolumn{2}{|c|}{ Enamel } & \multicolumn{2}{c|}{ Dentine } & \multicolumn{2}{c|}{ Cementum } \\
\cline { 2 - 7 } & $\begin{array}{c}\mathrm{Ca} \\
\mathrm{wt} \%\end{array}$ & $\begin{array}{c}\mathrm{P} \\
\mathrm{wt} \%\end{array}$ & $\begin{array}{c}\mathrm{C} \\
\mathrm{wt} \%\end{array}$ & $\begin{array}{c}\mathrm{P} \\
\mathrm{wt} \%\end{array}$ & $\begin{array}{c}\mathrm{Ca} \\
\mathrm{wt} \%\end{array}$ & $\mathrm{P}$ w $\%$ \\
\hline Group A & $34.65 \pm 0.40$ & $16.62 \pm 0.01$ & $6.95 \pm 0.01$ & $2.54 \pm 0.01$ & $2.23 \pm 0.01$ & $0.73 \pm 0.02$ \\
\hline Group B & $39.89 \pm 0.15$ & $18.54 \pm 0.01$ & $8.02 \pm 0.02$ & $4.38 \pm 0.01$ & $2.71 \pm 0.02$ & $1.15 \pm 0.01$ \\
\hline Group C & $44.53 \pm 0.16$ & $20.12 \pm 0.02$ & $9.60 \pm 0.06$ & $4.61 \pm 0.02$ & $2.99 \pm 0.008$ & $1.22 \pm 0.01$ \\
\hline Group D & $40.76 \pm 0.08$ & $18.85 \pm 0.01$ & $10.44 \pm 0.03$ & $5.12 \pm 0.02$ & $3.27 \pm 0.008$ & $1,34 \pm 0.01$ \\
\hline Ca: Calcium ion concentration \\
P: Phosphorous ion concentration \\
?
\end{tabular}

Table 3

MANN WHITNEY STATISTICAL TEST RESULTS (P VALUES) WHEN COMPARED MEAN CALCIUM ION CONCENTRATION IN GROUPS

\begin{tabular}{|c|c|c|c|c|c|c|c|c|c|c|c|c|}
\hline & \multicolumn{4}{|c|}{ Enamel } & \multicolumn{4}{|c|}{ Dentine } & \multicolumn{4}{|c|}{ Cementum } \\
\hline Groups & $\mathrm{A}$ & B & $\mathbf{C}$ & D & $\bar{A}$ & B & C & D & $\bar{A}$ & B & $\mathrm{C}$ & $\mathrm{D}$ \\
\hline$A$ & - & 0.009 & 0.009 & 0.009 & - & 0.009 & 0.009 & 0.009 & - & 0.009 & 0.008 & 0.008 \\
\hline B & 0.009 & - & 0.009 & 0.009 & 0.009 & - & 0.009 & 0.009 & 0.009 & - & 0.008 & 0.008 \\
\hline $\mathrm{C}$ & 0.009 & 0.009 & - & 0.008 & 0.009 & 0.009 & - & 0.009 & 0.008 & 0.008 & - & 0.008 \\
\hline D & 0.009 & 0.009 & 0.008 & - & 0.009 & 0.009 & 0.009 & - & 0.008 & 0.008 & 0.008 & - \\
\hline
\end{tabular}

Table 4

MANN WHITNEY STATISTICAL TEST RESULTS (P VALUES) WHEN COMPARED MEAN PHOSPHOROUS ION CONCENTRATION IN GROUPS

\begin{tabular}{|l|c|c|c|c|c|c|c|c|c|c|c|c|}
\hline & \multicolumn{4}{|c|}{ Enamel } & \multicolumn{4}{c|}{ Dentine } & \multicolumn{4}{c|}{ Cementum } \\
\hline Groups & A & B & C & D & A & B & C & D & A & B & C & D \\
\hline A & - & 0.008 & 0.008 & 0.009 & - & 0.009 & 0.009 & 0.009 & - & 0.009 & 0.008 & 0.008 \\
\hline B & 0.008 & - & 0.008 & 0.008 & 0.009 & - & 0.009 & 0.009 & 0.009 & - & 0.009 & 0.009 \\
\hline C & 0.008 & 0.008 & - & 0.008 & 0.009 & 0.009 & - & 0.009 & 0.009 & 0.009 & - & 0.009 \\
\hline D & 0.009 & 0.008 & 0.008 & - & 0.009 & 0.009 & 0.009 & - & 0.009 & 0.009 & 0.009 & - \\
\hline
\end{tabular}

an increase in calcium and phosphate concentration in order to maintain the fluid around the tooth in an oversaturated status. A more complete remineralization occurs when the concentrations of calcium and phosphate are lower, coming from saliva or from other topical sources, thus having the capacity of diffusing inside the tooth; with the help of fluoride or of another remineralizing agent, to rebuild the partially demineralized crystals rather than to form new crystals. The surface of rebuilt crystals is made of a facet of well-structured minerals; it is more resistant and less soluble to acid than the original mineral that contained a carbon apatite; the subsequent acid attacks will be less efficient [22].

The qualities necessary for an ideal remineralization agent are the following: (1) to release calcium and phosphate ions at the affected site (at the level of the subsurface lesion); (2) not to release calcium ions in excess; (3) not to favour the formation of plaque; (4) to be active at an acid $\mathrm{pH}$ acid in order to stop demineralization during the cariogenic attack; (5) to be active in the xerostomic patients, for whom saliva is not efficient in blocking the caries process; (6) to encourage remineralizing properties of saliva; (7) the new materials must present additional advantages compared to fluoride $[23,24]$.

During the time manufacturers tried to improve toothpastes content by adding different beneficial agents, except fluoride. Was demonstrated that calcium ions presence in the mouth has the capacity to limit the acid agression, to inhibittooth demineralization, and to enhance 
the remineralization process. Some of the calcium oral sourses are represented by calcium phosphate, calcium glycerophosphate, calcium carbonate dental products. In order to increase the concentration of calcium ions in oral biofilm and saliva, different calcium sourses can be combined.

Lack of studies are in the literature regarding the remineralization of incipient caries lesions using calcium carbonate products. The results of this study cannot be directly compared with the results of other studies. Positive changes in the mineral content reported in one previous study evaluated in fact the remineralization capacity of some products that contains calcium carbonate and arginine against dental erosion [25], or the effect of such products on dentine tubules closure [26-30]. The conclusions of Porcelli study indicated that arginine and calcium carbonate product was able to delay the development of erosive lesions. The arginine complex is responsible for the adhesion of calcium carbonate particles to the enamel surface and the dentin surface, which will allow calcium carbonate to dissolve slowly and to release calcium, which will encourage the remineralization of the hard dental tissues.

In our study all the tested toothpastes increased calcium and phosphorous ion concentrations in enamel, dentine and cement. The highest remineralization effect was recorded in enamel by Dentissiomo, followed by Arthrodent and EcoBio toothpastes. In dentine and cementum the highest remineralization effect was registered by Arthrodent, followed by Dentissiomo and EcoBio toothpastes. The low est remineralization capacity in enamel, dentine and cement was recorded for EcoBio toothpaste. Dentin contains an organic matrix mostly made of collagen fibres, which represent the matrix on top of which the hydroxyapatite crystals are situated. The remineralization of the dentin can be done either by precipitating the mineral ion between the collagen fibres or by binding it to its primary structure. Hence, a simple precipitation of the mineral onto the demineralized dentin matrix (net remineralization) provides an increased content in minerals, but it does not necessarily ensure an optimal interaction with the organic component of the matrix.

Future in vivo studies are needed to evaluate in the condition of oral cavity the effectiveness of these products on dental hard tissues remineralization.

\section{Conclusions}

Toothpastes that contain calcium carbonate and calcium glycerophosphate demonstrate significantly remineralization of caries lesion in vitro. Their remineralization effect is highlighted in present study in enamel, dentine, and also in cementum.

\section{References}

1.MUCENIC, S.G., CAMARASAN, A.C., FAZAKAS, Z., FULOP, E., ORMENISAN, A., MARIS, M., HANCU, V., TILINCA, M., Mat. Plast, 53, no. 3,2016, p. 386.

2.STOLERIU, S., PANCU, G., NICA, I., ANDRIAN, S., TOPOLICEANU, C., IOVAN, G., Mat. Plast, 53, no. 4, 2016, p. 752.
3.TOFAN, N., ANDRIAN, S., STOLERIU, S., NICA, I., MOLDOVANU, A., TOPOLICEANU, C., SOLOMON, O., PANCU, G., Mat. Plast, 55, no. 1, 2018, p. 129.

4.CIRDEI, M.V., MOCUTA, D., OGODESCU, E., PETCU, A., LAZEA, A., TODEA, C., Mat. Plast., 55, no. 2, 2018, p. 230.

5.SAVIN, C., PETCU, A., GAVRILA, L., MARTU-STEFANACHE, M.A., BALAN, A., International J ournal of Medical Dentistry, 20, no. 3, 2016, p. 171.

6.IOVAN, G., GHIORGHE, C.A., STOLERIU, S., PANCU, G., NICA, I., TARABOANTA, I., ANDRIAN, S., Mat. Plast, 55, no. 2, 2018, p. 233.

7.IOVAN, G., STOLERIU, S., PANCU, G., NICA, I., SANDU, A.V., ANDRIAN, S., TANCULESCU, O., Mat. Plast, 54, no. 2, 2017, p. 375.

8.TUNG, M.S., EICHMILLER, F.C., Compend. Contin. Educ. Dent., 25, no. 9 (suppl 1), 2004, p. 9.

9.COCHRANE, N.J., WALKER, G.D., MANTON, D.J ., REYNOLDS, E.C., Aust. Dent. J., 57. no. 3, 2012, p. 271.

10.SILVERSTONE, L.M., Proc. R. Soc. Med., 10, 1972, p. 906.

11.STOLERIU, S., IOVAN, G., PANCU, G., GEORGESCU, A., SANDU, A.V., ANDRIAN, S., Mat. Plast, 51, no. 2, 2014, p. 162.

12.AKIN, M., BASCIFTCI, F.A., Angle Orthod., 82, 2012, p. 770.

13.NIDHI, G., KUNWARJEET, S., J. Pharm. Biomed. Sci., 24, 2012, p. 79.

14.TAKAGI, S., LIAO, H., CHOW, L.C., Caries Res., 2000, 34, no. 4, p. 281.

15.ANDRIAN, S., IOVAN, G., GHIORGHE, A.C., PANCU, G., GEORGESCU, A., ANTONESCU, D.N., STOLERIU, S., Rev.Chim. (Bucharest), 68, no. 1, 2017, p. 134.

16.PANCU, G., ANDRIAN, S., IOVAN, G., NICA, I., GHIORGHE, A., SANDU, A.V., STOLERIU, S., Rev. Chim. (Bucharest), 67. no. 11, 2016, p. 2351. 17.PANCU, G., ANDRIAN, S., MOLDOVANU, A., NICA, I., SANDU, A.V., STOLERIU, S., Mat. Plast., 51, no. 4, 2014, p. 428.

18.GAVRILA. L., MAXIM, A., BALAN, A., STOLERIU, S., SANDU, A.V., SERBAN, V., SAVIN, C.,. Rev. Chim. (Bucharest), 66, no. 8, 2015, p. 1159.

19.PARNELL, C., GUGNANI, N., SHERRIFF, A., JAMES, P., BEIRNE, P.V., Cochrane Database Syst. Rev., 2012, doi: 10.1002/14651858.

20.POROCH, V., AGHEORGHIESEI, D.T., Postmodern Openings, 9 , no. 2, 2018, p. 225.

21.AGHEORGHIESEI CORODEANU, D.T., POROCH, V., 6th LUMEN International Conference on Rethinking Social Action Core Values, 16-19 April 2015, lasi, Romania, Rethinking Social Action. Core Values, p. 33.

22.MINI, K. J., BABU, A., GOPINATHAN, A.S., Int. J. Comm. Med. Public Health, 2, 2015, p. 10.

23.WALSH, L.J., Int. Dent. SA, 11, 2009, p. 614.

24.MIHALAS, E., MAXIM, A., BALAN, A., MATRICALA, L., MAXIM, D.C., TOMA, V., PETCU, A., Rev. Chim (Bucharest), 66, no. 6, 2015, p. 843. 25.PORCELLI, H.B.P., MAEDA, F.A., SILVA, B.R., MIRANDA JR., W.G., CARDOSO, P.E.C., Gen. Dent., July-August, 2015, p. 73.

26.STOLERIU, S., PANCU, G., GHIORGHE, A., SINCAR, D.C., SOLOMON, S., ANDRIAN, S., IOVAN, G., Rev. Chim (Bucharest), 68, no. 7, 2017, p. 1573.

27.SHARIF, M.O., IRAM, S., BRUNTON, P.A., 2013. J. Dent., 41, no. 6, p. 483.

28.CARSON, S.J ., Evid. Based Dent., 14, no. 2, 2013, p. 44. 29.PETCU, A., NEMTOI, A., PASCA, S., SINDILAR, E.V., HABA, D., PETRARIU, F.D., Rev. Chim (Bucharest), 66, no. 9, 2015, p. 1331. 30.BALAN, A., ANDRIAN, S., SAVIN, C., SANDU, A.V., PETCU, A., STOLERIU, S., Rev. Chim (Bucharest), 66, no. 4, 2015, p. 562.

Manuscript received: 22.08 .2018 